\title{
Taping Therapy Simultaneously applied to the Ankle and Hip Joint: Effect on Balance and Gait in Patients with Chronic Stroke
}

\author{
Young Jin Um', Ho Young Jang², Suk Min Lee ${ }^{3}$ \\ 'Department of Physical Therapy, Seoul Gimpo Airport Wooridul Spine Hospital, Seoul; ${ }^{2}$ Department of Physical Therapy, St. Paul's Hospital, The \\ Catholic University; ${ }^{3}$ Department of Physical Therapy, College of Health and Welfare, Sahmyook University, Seoul, Korea
}

Purpose: This study examined the effects of taping therapy on the balance and gait of stroke patients.

Methods: The subjects of this study were 30 stroke patients. The treatment groups were prescribed a combination of taping, therapy applied simultaneously to the ankle and the hip joint, and general physical therapy twice a day for 30 minutes each, five days per week for 4 weeks for a total of 40 times. The control group was treated with general physical therapy for 30 minutes, 5 times per week for 4 weeks, and total 40 times. All subjects were followed up on a Berg balance scale, timed up and go test, activity-specific balance confidence scale, and GaitRite.

Results: The group that simultaneously received taping therapy to the ankle and hip joint showed more significant effects than the group treated with ankle joint taping only $(p<0.05)$. Effects were noted in the Berg balance scale, timed up and go test, activity-specific balance confidence scale and gait ability test. Compared to the control group, the group treated at the ankle and hip joint showed significant effects after the experiment in the Berg balance scale, timed up and go test, activity-specific balance confidence scale, and gait ability test $(p<0.05)$.

Conclusion: Taping therapy applied to both the ankle and hip joints, and combined with general physical therapy appears to be effective in patients with chronic stroke who have an impaired balance and gait ability.

Keywords: Stroke, Taping, Balance, Gait

\section{서 론}

뇌졸중 환자는 감각손상, 운동기능 손상, 인지 및 시지각 장애가 나 타나고, 균형 능력 저하, 보행 속도, 보행 지구력 감소로 인해 독립적 인 보행이 어려운 기능 장애를 가지고 있으며, 이 중 뇌졸중 환자들에 게서 삶에 큰 영향을 줄 수 있는 기능적 결함은 균형 능력과 보행 능 력의 저하이다.

뇌졸중 환자에게 있어 균형의 유지는 체성감각계, 전정계 및 시각 계, 고유수용성감각계, 근골격계, 중추신경계에서 수행하는 지속적 이고 복합적인 상호작용으로 자세를 유지하고 수의적 운동을 하는 동안 자세를 안정시킴으로써 이동하거나 독립적인 보행 등 일상생활 동작을 수행하는 데 있어 중요한 항목이다. 또한 뇌졸중 환자들은 정상인에 비해 정적 자세에서의 자세동요가 증가하면서 양 하지에
비대칭적으로 체중이 부하되고, 마비 측으로 무게중심 이동 능력이 저하된다. ${ }^{2}$ 자세동요에 따른 선 자세에서의 균형을 유지하기 위해 발 목관절 전략이나 엉덩관절 전략 또는 두 가지 전략을 함께 사용한다.

보행 능력의 저하는 뇌졸중 후 대부분의 환자에서 나타나는 장애 로, ${ }^{3}$ 환자는 보행 능력의 일부를 회복하는 데 있어 보행 시 $40 \%$ 는 도 움이 필요하고, $60 \%$ 는 독립보행이 가능하나, ${ }^{4}$ 집 밖에서 독립적으로 이동할 수 있는 능력에 있어서는 제한을 받는다. ${ }^{5}$ 재활 치료에도 불구 하고, 하지 쪽 마비의 약 $35 \%$ 뇌졸중 환자들은 보행 능력과 기능에 있 어 회복하지 못하며, 모든 뇌졸중 환자 중 $25 \%$ 는 퇴원하기 전 다른 사 람의 보조 없이 보행하기 어렵다. ${ }^{6}$ 뇌졸중 후 보행 기능은 대부분 신 경학적 보행 장애로 조사되었으며, 이로 인한 보행 장애는 뚜렷한 비 대칭적 문제로 나타나게 된다. 따라서 뇌졸중 후 보행 회복은 주요한 재활 목표 중 하나가 될 수 있을 것이다. 
하나의 중재로서 테이핑이 추천되는데 테이핑의 적용은 관절을 지 지하고 보호하여 기능적인 움직임을 수행할 수 있도록 하며, 이러한 외적 지지는 인대의 보강과 움직임의 제한을 통해 관절의 안정성을 향상시킬 수 있다. 뇌졸중 환자를 대상으로 한 테이핑의 적용은 보행 능력의 향상과 일상생활동작 수행능력의 증진을 가져올 수 있다. 뇌 졸중 환자의 보행 중 입각기 시 큰볼기근에 비탄력 테이핑을 적용 후 엉덩관절의 신전이 향상되었으며, ${ }^{7}$ 균형 및 보행 능력을 향상시키기 위한 하지 자세 바른 정렬은 필수적이라고 하였다. 또한 발목관절의 테이핑은 감거나 붙이는 적용방법에 따라 기계적 지지 및 자극을 촉 진할 수 있으며, 접촉된 테이핑으로 피부수용성 신호를 더욱 강하게 전달하며, 고유수용성 감각 향상 및 관절의 바른 정렬을 촉진하여 관 절의 안정성을 향상시켜 균형과 보행 능력의 향상을 이끌 수 있다고 하였다. ${ }^{8}$ 또한 균형 및 보행 능력의 향상과 관련된 근거로 고유수용성 되먹임 기전을 통하여 발목관절 근육들의 동원시간을 단축시키는 것을 제시하였다.

따라서 본 연구는 발목관절과 엉덩관절에 테이핑 요법을 동시 적 용하여 만성 뇌졸중 환자의 균형 및 보행과 관련된 치료적 효과를 알 아봄으로써 만성 뇌졸중 환자를 대상으로 임상에서 중재 근거로 사 용하고자함에 있다.

\section{연구 방법}

\section{1. 연구의 대상 및 절차}

1) 연구의 대상

본 연구의 대상자는 경기도 소재 $\mathrm{C}$ 병원에 내원하는 만성 뇌졸중 환 자 30 명을 대상으로 본 연구를 이해하고 적극적으로 참여 의사를 밝 힌 자로, 연구 참여에 동의한 후 진행하였다.

연구 대상자의 선정조건으로는 뇌졸중 발병 후 6개월 이상 경과한 자로 $15 \mathrm{~m}$ 이상 독립 보행이 가능한 자, 지시하는 내용을 이해할 수 있는 자(MMSE-K 24점 이상)로 하였다. 연구대상자의 제외조건은 실 험을 진행하기 어려운 근골격계 문제가 있는 자, 테이핑 요법을 적용
하는 데 제한되는 특이한 피부계 질환이 있는 자, 의사소통이 불가능 한 자, 그 외 연구자의 판단으로 참여가 불가능한 자로 하였다.

본 연구는 삼육대학교 생명윤리심의위원회의 승인을 받은 후 시행 되었다(2-1040781-AB-N-01-2016126HR).

\section{2) 연구의 절차}

모든 연구대상자는 실험 전과 실험 후 일어나 걸어가기 검사, 버그 균 형척도, 균형 자신감 척도, 보행 분석기를 이용한 보행 능력 검사를 실시하였다. 연구대상자는 제비뽑기를 이용하여 발목관절 테이핑군 $(\mathrm{n}=10)$ 과 발목관절과 엉덩관절에 동시 적용한 테이핑군 $(\mathrm{n}=10)$, 일반 적인 물리치료군 $(\mathrm{n}=10)$ 으로 각각 실험을 실시하였다. 두 실험군은 각 각 발목관절 테이핑 요법을 적용, 발목관절과 엉덩관절에 동시 적용 한 테이핑 요법 후 일반적 물리치료를 각각 1 일 30 분씩 2 회, 주 5 회, 4 주간 실시하였고, 대조군은 일반적 물리치료를 1 일 30 분씩 2 회, 주 5 회, 4 주간 실시하였다.

본 연구의 참가자는 지정된 스케줄에 따라 훈련 프로그램에 참여 하였다. 본 연구의 실험진행을 위한 임상경력 3년 이상의 물리치료사 6명을 두어 연구를 진행하며 각 실험과 측정에 들어가기 전 장비 사 용, 검사도구 측정, 실험 진행에 대한 교육 및 실습을 진행하여 실험 과정에서 생길 수 있는 안전사고와 오류를 최소화하도록 하였다.

\section{2. 실험 방법}

1) 테이핑 요법과 일반적 물리치료

본 연구는 탄력 테이프와 비탄력 테이프를 이용하였으며 탄력 테이 프는 Benefact $(5.0 \mathrm{~cm} \times 5 \mathrm{~m}$, NipponSigmax, 국가명, 2017)를 사용하였 고, 비탄력테이프는 Endura-sportstap (Minneapolis, USA, 2016)을 사 용하였다. 피부 면에 오염물을 제거한 뒤 연구 담당자가 적용하였고 운동치료가 끝난 직후 제거하였다.

\section{(1) 발목관절 테이핑}

발목관절 테이핑 부착은 탄력 테이프를 이용하였으며 발목관절을
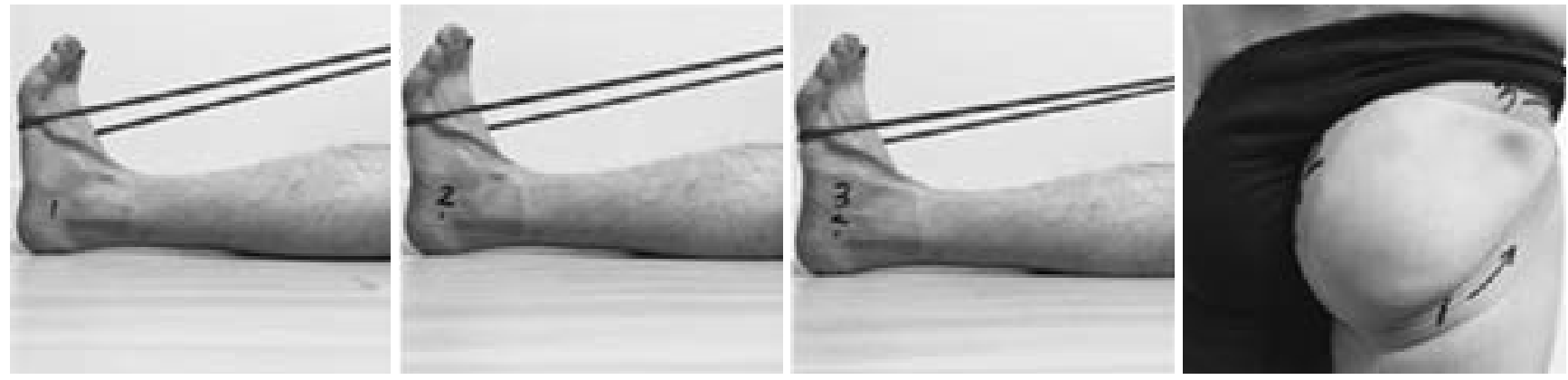

Figure 1. Hip joint taping and ankle joint taping. 
감싸듯이 적용하였다. 족관절을 배측굴곡과 내회전을 시킨 후 medial malleolus 2-3cm 위쪽부터 잡아당기면서 발목관절을 감싸고 planta surface를 지나 lateral malleolus 위 proximal에서 distal쪽으로 적용하 여 총 3개의 탄력테이프를 반씩 겹치게 적용하였다(Figure 1).

\section{(2) 엉덩관절 테이핑}

엉덩관절 테이핑 적용은 비탄력 테이프를 이용하였으며, 마비측 볼 기근 주변을 감싸듯이 적용하였다. 환자들이 편안하게 기립한 자세 에서 실시하였으며, 첫 번째는 볼기근 하내측에서 테이핑을 약간 잡 아당기면서 외측 상부방향인 대전자 쪽으로 적용하였다. 두 번째는 볼기근 하내측에서 테이핑을 약간 잡아당기면서 큰볼기근 근복 (muscle belly)을 지나 상방방향으로 적용하였다. 세 번째 테이핑은 두 번째 테이핑이 끝난 부분에서 대전자 방향으로 적용하였다(Figure 1).

\section{(3) 일반적인 물리치료}

실험군과 대조군에서 모두 동일한 신경계 물리치료 프로그램을 시행 하였다. 신경계 물리치료 프로그램은 보바스의 신경발달치료와 고유 수용성 신경근 촉진법을 이용하였으며, 본 운동 프로그램으로는 일 반적으로 뇌졸중 환자의 재활에 많이 사용되는 방법으로 Davies와 Gjelsvik이 제안한 트레이닝 프로그램에 근거하여 구성 하였다.

\section{3. 측정 도구와 자료 수집 과정}

본 연구에서는 균형 능력을 평가하기 위해 일어나 걸어가기 검사 (timed up and go test, TUG)와 버그 균형척도(Berg balance scale, BBS), 균형 자신감 척도(activity-specific balance confidence scale, ABC scale) 를 이용하였으며, 보행 능력을 평가하기 위해 보행 분석기(GAITRite, CIR System Inc, USA 2008)를 이용하였다. 그중 TUG는 동적 균형 능 력과 기능적 이동성을 정량화하고 시간 경과에 따른 임상적 변화를 측정하는 데 신뢰도와 타당도가 입증되었다. 정상 남성의 TUG는 평 균 8-13.1초로 알려져 있으며, 신경학적 손상이 없는 정상인에서는 10 초 미만이 걸리는 것으로 조사되었다. ${ }^{9}$ Finch 등 10 은 10 초 미만일 경우
독립적인 균형 능력을 가지고 있고 20초에서 30 초 사이에선 독립적이 나 낙상의 위험을 가지며 30초 이상은 일상생활에 의존이 필요하다 는 것으로 나타났다.

\section{4. 분석 방법}

본 연구의 모든 작업과 통계는 SPSS ver. 19.0 (IBM Co, Armonk, NY, USA)을 이용하여 평균 및 표준편차를 산출하였다. 전체 대상자의 일 반적인 특성과 변수에 대한 정규성 검증을 하였으며, 그룹 내 전후차 이를 알아보기 위해서 대응표본 $\mathrm{t}$-검정을 실시하였다. 집단 간 차이를 알아보기 위하여 일원배치분산분석(one way ANOVA test)을 실시하 였으며, 사후분석은 Bonferroni 검정을 사용하였다. 자료의 모든 통계 학적 유의수준은 0.05 로 설정하였다.

\section{연구 결과}

\section{1. 연구 대상자의 일반적 특성}

본 실험에서의 대상자는 만성 뇌졸중 환자 30 명으로 발목관절과 엉 덩관절 동시적용 테이핑군 10 명, 발목관절 테이핑군 10 명, 대조군 10 명으로 하였다(Table 1).

\section{2. 실험에 따른 균형 능력의 변화}

균형 능력의 변화를 알아보기 위해 일어나 걸어가기 검사, 버그 균형 척도, 균형 자신감 척도를 실시했으며 다음의 결과를 얻었다.

\section{1) 일어나 걸어가기 검사(TUG) 결과}

일어나 걸어가기 검사는 발목관절과 엉덩관절 동시적용 테이핑군의 경우 적용 전 36.11 초에서 27.46 초로 유의하게 감소하였고 $(\mathrm{p}<0.05)$, 발 목관절 테이핑군의 경우 35.78 초에서 31.59 초로 유의하게 감소하였고 $(\mathrm{p}<0.05)$, 일반적인 물리치료군의 경우 37.55 초에서 36.22 초로 유의하 게 감소하였다 $(\mathrm{p}<0.05)$. 모든 군에서 일어나 걸어가기 검사 점수 변화 에 대하여 유의한 감소를 보였다. 세 그룹 간 중재 전과 후의 차이는

Table 1. Patient characteristics

$(n=30)$

\begin{tabular}{lcccc}
\hline & $\begin{array}{c}\text { Hip and ankle joint taping } \\
\text { group }(n=10)\end{array}$ & $\begin{array}{c}\text { Ankle joint taping } \\
\text { group }(n=10)\end{array}$ & Control & group $(n=10)$ \\
\hline Age (yr) & $59.79 \pm 11.05$ & $59.30 \pm 13.16$ & $51.10 \pm 15.00$ & $1.392(0.266)$ \\
Height (cm) & $170.40 \pm 5.13$ & $165.50 \pm 9.48$ & $171.50 \pm 3.98$ & $2.320(0.118)$ \\
Weight (kg) & $68.80 \pm 6.39$ & $65.50 \pm 9.98$ & $70.40 \pm 6.67$ & $1.013(0.377)$ \\
Injury period (Month) & $13.20 \pm 5.71$ & $14.70 \pm 5.01$ & $15.30 \pm 3.23$ & $0.515(0.603)$ \\
MMSE-K (Point) & $26.90 \pm 1.79$ & $26.10 \pm 1.91$ & $26.20 \pm 1.55$ & $0.615(0.548)$ \\
Injury subtype (Infarction/hemorrhage) & $5 / 5$ & $4 / 6$ & $8 / 2$ & $4 / 6$ \\
Affected side (Right/left) & $4 / 6$ & $6 / 4$ & $8 / 2$ & \\
Sex (Male/female) & $7 / 3$ & $6 / 4$ & & \\
\hline
\end{tabular}


Table 2. Results in timed up and go test following intervention

\begin{tabular}{lcccc}
\hline & $\begin{array}{c}\text { Hip and ankle joint taping } \\
\text { group }(n=10)^{A}\end{array}$ & $\begin{array}{c}\text { Ankle joint taping } \\
\text { group }(n=10)^{B}\end{array}$ & $\begin{array}{c}\text { Control } \\
\text { group }(n=10)^{\mathrm{C}}\end{array}$ & $F(p)$ \\
\hline Pre & $36.11^{\mathrm{a}} \pm 10.53$ & $35.78 \pm 11.26$ & $37.55 \pm 9.40$ & \\
Post & $27.43 \pm 9.03$ & $31.59 \pm 11.04$ & $36.22 \pm 9.02$ & \\
$\mathrm{t}(\mathrm{p})$ & $8.041(0.000)^{*}$ & $7.333(0.000)^{*}$ & $6.566(0.000)^{*}$ & $26.791(0.000)^{*} \mathrm{~A}|\mathrm{~B}| \mathrm{C}$ \\
\hline
\end{tabular}

Mean \pm standard deviation

A: hip and ankle joint taping, B: ankle joint taping, C: control group, D: mean \pm standard deviation, ${ }^{\star} p<0.05$.

Table 3. Results in berg balance scale following intervention

$(n=30)$

\begin{tabular}{lcccc}
\hline & Hip and ankle joint taping & Ankle joint taping & Control & \\
& group $(n=10)^{A}$ & group $(n=10)^{B}$ & group $(n=10)^{\mathrm{C}}$ & \\
\hline Pre & $32.10^{\mathrm{a}} \pm 4.86$ & $31.60 \pm 4.43$ & $31.70 \pm 4.40$ & \\
Post & $38.40 \pm 4.70$ & $34.60 \pm 3.98$ & $33.10 \pm 3.90$ & \\
$\mathrm{t}(\mathrm{p})$ & $-11.275(0.000)^{*}$ & $-8.216(0.000)^{*}$ & $-4.583(0.001)^{*}$ & $34.757(0.000)^{*} \mathrm{~A}|\mathrm{~B}| \mathrm{C}$ \\
\hline
\end{tabular}

Mean \pm standard deviation.

A: hip and ankle joint taping, B: ankle joint taping, C: control group, D: mean \pm standard deviation, ${ }^{*} p<0.05$.

Table 4. Results in activity-specific balance confidence scale following intervention

\begin{tabular}{lcccc}
\hline & Hip and ankle joint taping & Ankle joint taping & Control & \\
& group $(n=10)^{A}$ & group $(n=10)^{B}$ & group $(n=10)^{\mathrm{C}}$ & \\
\hline Pre & $36.41^{\mathrm{a}} \pm 12.85$ & $36.12 \pm 12.01$ & $37.42 \pm 13.53$ & \\
Post & $45.43 \pm 13.09$ & $40.45 \pm 12.01$ & $39.64 \pm 13.00$ & \\
$\mathrm{t}(\mathrm{p})$ & $-5.612(0.000)^{*}$ & $-6.470(0.000)^{*}$ & $-5.180(0.001)^{*}$ & $11.312(0.000)^{*} \mathrm{~A}|\mathrm{~B}| \mathrm{C}$ \\
\hline
\end{tabular}

Mean \pm standard deviation.

A: hip and ankle joint taping, B: ankle joint taping, C: control group, D: mean \pm standard deviation, * $p<0.05$.

Table 5. Results in gait speed following intervention

$(n=30)$

\begin{tabular}{lcccc}
\hline & Hip and ankle joint taping & Ankle joint taping & Control & \\
& group $(n=10)^{A}$ & group $(n=10)^{B}$ & group $(n=10)^{\mathrm{C}}$ & \\
\hline Pre & $48.83^{\mathrm{B}} \pm 3.95$ & $49.22 \pm 5.30$ & $48.83 \pm 3.95$ & \\
Post & $57.63 \pm 3.98$ & $55.41 \pm 5.49$ & $57.63 \pm 3.98$ & \\
$\mathrm{t}(\mathrm{p})$ & $-18.771(0.000)^{*}$ & $-15.907(0.000)^{*}$ & $-10.480(0.000)^{*}$ & $25.195(0.000)^{*} \mathrm{~A}|\mathrm{~B}| \mathrm{C}$ \\
\hline
\end{tabular}

Mean \pm standard deviation.

A: hip and ankle joint taping, B: ankle joint taping, C: control group, D: mean \pm standard deviation, ${ }^{*} p<0.05$.

발목관절과 엉덩관절 동시적용 테이핑군이 발목관절 테이핑군, 일반 적인 물리치료군보다 더 효과적이었다 $(\mathrm{p}<0.05)($ Table 2$)$.

\section{2) 버그 균형척도(BBS) 결과}

버그 균형척도는 발목관절과 엉덩관절 동시적용 테이핑군의 경우 적 용 전 32.10점에서 38.40점으로 유의하게 증가하였고 $(\mathrm{p}<0.05)$, 발목관 절 테이핑군의 경우 31.60 점에서 34.60점으로 유의하게 증가하였고 $(\mathrm{p}<0.05)$, 일반적인 물리치료군의 경우 31.70 점에서 33.10 점으로 유의 하게 증가하였다 $(\mathrm{p}<0.05)$. 모든 군에서 버그 균형척도 점수 변화에 대 하여 유의한 향상을 보였다. 세 그룹 간 중재 전과 후의 차이는 발목 관절과 엉덩관절 동시적용 테이핑군이 발목관절 테이핑군, 일반적인 물리치료군보다 더 효과적이었다 $(\mathrm{p}<0.05)$ (Table 3$)$.
3) 균형 자신감 척도(ABC scale) 결과

균형 자신감 척도는 발목관절과 엉덩관절 동시적용 테이핑군의 경우 적용 전 36.41점에서 45.43점으로 유의하게 증가하였고 $(\mathrm{p}<0.05)$, 발목 관절 테이핑군의 경우 36.12 점에서 40.45점으로 유의하게 증가하였고 $(\mathrm{p}<0.05)$, 일반적인 물리치료군의 경우 37.42점에서 39.64점으로 유의 하게 증가하였다 $(\mathrm{p}<0.05)$. 모든 군에서 균형 자신감 척도 점수 변화 에 대하여 유의한 향상을 보였다. 세 그룹 간 중재 전과 후의 차이는 발목관절과 엉덩관절 동시적용 테이핑군이 발목관절 테이핑군, 일반 적인 물리치료군보다 더 효과적이었다 $(\mathrm{p}<0.05)($ Table 4$)$.

\section{3. 보행 능력의 변화}

보행 능력의 변화는 보행속도와 분속수의 변화와 마비측과 비마비 측의 보장과 활보장의 변화를 평가하여 다음과 같은 결과를 얻었다. 


\section{1) 보행속도의 변화}

보행속도는 발목관절과 엉덩관절 동시적용 테이핑군의 경우 적용 전 $48.83 \mathrm{~cm} / \mathrm{sec}$ 에서 $57.63 \mathrm{~cm} / \mathrm{sec}$ 로 유의하게 증가하였고 $(\mathrm{p}<0.05)$, 발목관 절 테이핑군의 경우 $49.22 \mathrm{~cm} / \mathrm{sec}$ 에서 $55.41 \mathrm{~cm} / \mathrm{sec}$ 로 유의하게 증가하였 고 $(\mathrm{p}<0.05)$, 일반적인 물리치료군의 경우 $48.83 \mathrm{~cm} / \mathrm{sec}$ 에서 $57.63 \mathrm{~cm} / \mathrm{sec}$ 으로 유의하게 증가하였다 $(\mathrm{p}<0.05)$. 모든 군에서 보행 속도 변화에 대 하여 유의한 향상을 보였다. 세 그룹 간 중재 전과 후의 차이는 발목관 절과 엉덩관절 동시적용 테이핑군이 발목관절 테이핑군과 일반적인 물 리치료군보다 더 통계학적으로 유의한 차이가 있었다 $(\mathrm{p}<0.05)($ Table 5).

\section{2) 분속수의 변화}

분속수는 발목관절과 엉덩관절 동시적용 테이핑군의 경우 적용 전 $75.08 \mathrm{step} / \mathrm{min}$ 에서 $82.84 \mathrm{step} / \mathrm{min}$ 으로 유의하게 증가하였고 $(\mathrm{p}<0.05)$, 발목관절 테이핑군의 경우 $74.82 \mathrm{step} / \mathrm{min}$ 에서 $80.65 \mathrm{step} / \mathrm{min}$ 으로 유 의하게 증가하였고 $(\mathrm{p}<0.05)$, 일반적인 물리치료군의 경우 $74.37 \mathrm{step} /$ $\min$ 에서 $78.41 \mathrm{step} / \mathrm{min}$ 으로 유의하게 증가하였다 $(\mathrm{p}<0.05)$. 모든 군에 서 보행 속도 변화에 대하여 유의한 향상을 보였다. 세 그룹 간 중재 전과 후의 차이는 발목관절과 엉덩관절 동시적용 테이핑군이 발목 관절 테이핑군, 일반적인 물리치료군보다 더 통계학적으로 유의한차 이가 있었다 $(\mathrm{p}<0.05)$.

\section{3) 마비측과 비마비측의 보장의 변화}

보장은 발목관절과 엉덩관절 동시적용 테이핑군의 경우 적용 전 마비 측 $41.34 \mathrm{~cm}$, 비마비측 $34.73 \mathrm{~cm}$ 에서 마비측 $48.47 \mathrm{~cm}$, 비마비측 41.42 $\mathrm{cm}$ 로 유의하게 증가하였고 $(\mathrm{p}<0.05)$, 발목관절 테이핑군의 경우 마비 측 $37.55 \mathrm{~cm}$, 비마비측 $37.35 \mathrm{~cm}$ 에서 마비측 $42.72 \mathrm{~cm}$, 비마비측 42.48 $\mathrm{cm}$ 로 유의하게 증가하였고 $(\mathrm{p}<0.05)$, 일반적인 물리치료군의 경우 마 비측 $41.34 \mathrm{~cm}$, 비마비측 $44.66 \mathrm{~cm}$ 에서 마비측 $39.15 \mathrm{~cm}$, 비마비측 42.30 $\mathrm{cm}$ 로 유의하게 증가하였다 $(\mathrm{p}<0.05)$. 모든 군에서 보행 속도 변화에 대 하여 유의한 향상을 보였다. 세 그룹 간 중재 전과 후의 차이는 발목관 절과 엉덩관절 동시적용 테이핑군이 발목관절 테이핑군, 일반적인 물 리치료군보다 더 효과적이었다 $(\mathrm{p}<0.05)$.

\section{4) 마비측과 비마비측의 활보장의 변화}

활보장은 발목관절과 엉덩관절 동시적용 테이핑군의 경우 적용 전 마비측 $80.25 \mathrm{~cm}$, 비마비측 $79.86 \mathrm{~cm}$ 에서 마비측 $86.92 \mathrm{~cm}$, 비마비측 $86.57 \mathrm{~cm}$ 로 유의하게 증가하였고 $(\mathrm{p}<0.05)$, 발목관절 테이핑군의 경우 마비측 $73.18 \mathrm{~cm}$, 비마비측 $74.53 \mathrm{~cm}$ 에서 마비측 $78.18 \mathrm{~cm}$, 비마비측 $79.84 \mathrm{~cm}$ 로 유의하게 증가하였고 $(\mathrm{p}<0.05)$, 일반적인 물리치료군의 경 우 마비측 $83.62 \mathrm{~cm}$, 비마비측 $83.62 \mathrm{~cm}$ 에서 마비측 $86.54 \mathrm{~cm}$, 비마비 측 $86.87 \mathrm{~cm}$ 로 유의하게 증가하였다 $(\mathrm{p}<0.05)$. 모든 군에서 보행 속도
변화에 대하여 유의한 향상을 보였다. 세 그룹 간 중재 전과 후의 차 이는 발목관절과 엉덩관절 동시적용 테이핑군이 발목관절 테이핑군, 일반적인 물리치료군보다 더 효과적이었다 $(\mathrm{p}<0.05)$.

\section{고 찰}

\section{1. 균형 능력의 변화}

균형이란 기저면 내에서 신체와 무게중심을 유지하기 위해 지속적으 로 이루어지는 자세의 조절과 적응 과정을 의미하며, 이는 감각 중추 신경계, 운동 중추신경계 그리고 조절된 움직임에 의해 생성되는 복 합적인 과정이다. Eva 등은 뇌졸중 환자의 균형 능력 감소 요인을 관 절 움직임의 감소, 근 긴장도의 변화, 근육약화, 통증, 시 지각 능력의 소실, 고유수용성 감각의 저하 등으로 나눌 수 있다고 하였으며, 균형 능력 저하와 더불어 고유수용성 감각이 감소되면 보행 중 하지의 관 절 부하 및 위치 인식능력에 문제를 초래하여 환자가 균형을 잡는데 더 큰 어려움을 나타나게 한다. 이러한 균형의 문제점들은 일상생활 동작과 운동 회복을 방해하고 낙상의 위험을 증가시키는 원인으로 작용하고 있다."

일반적으로 균형 조절 능력의 변화를 평가하는 많은 방법들이 개 발되어 왔으며, 표준화된 평가 방법으로는 버그 균형척도, 일어나 걸 어가기 검사 등이 특별한 기구 없이도 균형조절능력을 평가할 수 있 어 임상적으로 널리 사용되고 있다. ${ }^{2}$ 그중 일어나 걸어가기 검사는 동 적 균형 능력과 기능적 이동성을 정량화하고 시간 경과에 따른 임상 적 변화를 측정하는 데 신뢰도와 타당도가 입증되었다.

본 연구에서 시행한 일어나 걸어가기 검사는 발목관절과 엉덩관 절 동시적용 테이핑군의 경우 적용 전 36.11 초에서 27.46 초로 유의하 게 감소하였고 $(\mathrm{p}<0.05)$, 모든 군에서 일어나 걸어가기 검사 점수 변화 에 대하여 유의한 감소를 보였다. 세 그룹 간 중재 전과 후의 차이는 발목관절과 엉덩관절 동시적용 테이핑군이 발목관절 테이핑군, 일반 적인 물리치료군보다 더 효과적이었다 $(\mathrm{p}<0.05)$. 이는 발목관절과 엉 덩관절 동시적용 테이핑을 통해서 하지의 위치 감각, 다양한 체중 지 지율의 증가와 그에 따른 균형 능력이 향상된 것으로 생각된다.

버그 균형척도는 노인성 질환과 뇌졸중으로 인한 편마비 환자의 이동이나 선 자세에서의 균형 능력을 측정하는 데 널리 사용되고 있 다. 본 연구에서 시행한 버그 균형척도에서는 발목관절과 엉덩관절 동시적용 테이핑군의 경우 적용 전 32.10점에서 38.40점으로 유의하 게 증가하였고 $(\mathrm{p}<0.05)$ 모든 군에서 버그 균형척도 점수 변화에 대하 여 유의한 향상을 보였다. 세 그룹 간 중재 전과 후의 차이는 발목관 절과 엉덩관절 동시적용 테이핑군이 발목관절 테이핑군, 일반적인 물 리치료군보다 더 효과적이었다 $(\mathrm{p}<0.05)$. 본 연구에서는 선행연구의 연구 결과와 일치하였다. 이는 발목관절과 엉덩관절 동시적용 테이핑 
이 반사적 자세 제어와 함께 자동적 반응의 향상을 통하여 자세의 안 정성이 무너지는 것을 막고 발목 관절 주위 근육을 수축시킴으로써 안정성을 강화해 주는 효과로 사료된다.

균형 자신감 척도는 서열척도로 구성된 평가도구로서 신뢰도와 타 당도를 인정받았으며 균형의 여러 요인들을 평가하고, 임상에서 사용 하기에 적합하다고 하였다. 또한, 균형자신감은 활동성 및 참여도와 매우 밀접한 관련성을 가지고 있으며, 이러한 환자의 참여도와 활동 성을 높이는 요인으로 보행속도가 크게 작용한다고 하였다. Lee 등12 은 만성 뇌졸중 환자를 대상으로 균형 훈련군과 대조군을 비교한 후, 실험 전후 균형 자신감 척도와의 유의한 차이를 확인하였다. 본 연구 에서 시행한 균형 자신감 척도에서는 발목관절과 엉덩관절 동시적용 테이핑군의 경우 적용 전 36.41점에서 45.43점으로 유의하게 증가하였 고 $(\mathrm{p}<0.05)$ 모든 군에서 균형 자신감 척도 점수 변화에 대하여 유의한 향상을 보였다. 세 그룹 간 중재 전과 후의 차이는 발목관절과 엉덩관 절 동시적용 테이핑군이 발목관절 테이핑군, 일반적인 물리치료군보 다 더 효과적이었다 $(\mathrm{p}<0.05)$. 이는 발목관절과 엉덩관절 동시적용 테 이핑이 뇌졸중 환자의 균형과 보행 능력의 향상에 따라 환자의 참여 도, 활동성도 함께 증가 요인으로 작용하여 균형자신감이 높아진 것 으로 생각되며, 선행연구의 결과와 일치한다는 것이 입증되었다.

본 연구에서는 뇌졸중 환자에게 발목관절과 엉덩관절 동시적용 테이핑을 시행하여 균형 능력이 향상됨을 확인하였다. 이는, 하지의 근 활성도와 관련해서 불안정한 지지면에 대항해 균형을 유지시키기 위해 신체 분절을 지나는 근육들의 공동 수축이 발생한다고 하였으 며, 하지의 불안정 방향이 증가함으로 근 활성도가 높게 나타나는 것 은 안정성의 감소에 따라 균형 유지를 위한 안정성 확보를 위하여 근 활성도가 증가함을 의미한다 하였다. ${ }^{13}$ 또한, 불안정한 면에서의 균형 훈련은 관절의 운동성, 신경근 조절에 대한 정상화 그리고 동적관절 조절이 필요한 구심성 자극에 대한 무의식적인 운동반응을 강화하 고, ${ }^{14}$ 이러한 지속적인 자극이 감마 운동신경원을 통하여 근방추를 민감하게 만들어 줌으로써 결과적으로, 알파 운동신경원으로 전달 되어 근섬유를 활성화 시켜 운동 출력을 개선시키며, 그것은 관절의 안정성에 긍정적인 영향을 미친다고 하였다.

따라서 본 연구에서의 균형 능력의 증진의 효과로는 불안정한 면에 서 발목관절과 엉덩관절 동시적용 테이핑으로 인하여 하지의 근 활성 도가 증가하고 그로 인한 관절의 안정성 또한 향상된 효과로 사료된다.

\section{2. 보행 능력의 변화}

보행은 인간의 근골격계와 신경계 등이 총괄적으로 사용되는 복잡한 과정이며 편측이 입각기의 안정된 상태를 유지하는 동안 동시에 다른 편측은 몸을 앞으로 움직이게 하는 연속적이고 반복적인 동작이다.

뇌졸중 환자는 정상적인 수준의 수의적인 근 수축을 생성할 능력
이 부족하고, 근 동원 순서가 부적절하며, 근 활성의 강도조절이 어려 워 보행 능력이 감소되며, ${ }^{14} \operatorname{Lin}$ 등은 뇌졸중 환자의 부적절한 발목관 절에 대한 위치감각은 큰 보행 편차를 발생시킨다고 하였으며 또한 고유수용감각 저하는 균형 조절 능력의 손상을 동반하기 때문에 보 행 시 큰 어려움을 일으키게 된다고 하였다. 이러한 뇌졸중 환자의 비 정상적 보행은 일상생활에서 이동을 어렵게 하고 이와 함께 보행 속 도를 감소시키는 주된 요인이라고 하였으며, Roth 등은 보행속도의 감소와 더불어 보행의 시-공간적인 변수에 변화를 초래하는데 그중 보장과 분속수는 보행 속도와 관련하여 감소되는 양상을 보인다고 하였다. 또한 여러 연구들에서 뇌졸중 환자의 마비측과 비마비측의 보장과 분속수의 감소 등이 나타난다고 하였다.

보행에 관한 선행연구에서 Holden 등다에 의하면 일반적 보행과 계 단 보행을 독립적으로 수행하고 최소한의 기능적 보행을 유지하기 위 한 보행 속도는 $60 \mathrm{~cm} / \mathrm{sec}$ 라고 보고하였다. Lunstord와 Perry ${ }^{16}$ 에 의하면 지역 사회 보행을 위한 최소 보행 속도는 $42 \mathrm{~cm} / \mathrm{sec}$ 라고 하였고, $40 \mathrm{~cm} /$ $\mathrm{sec}$ 이하는 실내에서의 보행, $40-80 \mathrm{~cm} / \mathrm{sec}$ 는 제한된 지역사회에서의 보 행, $80 \mathrm{~cm} / \mathrm{sec}$ 이상은 완전 독립 보행으로 분류하였다. 또 다른 보행에 관한 연구에서, Edward 등17은 분속수가 89-131 step/min이고 보폭이 108-163 cm라고 보고하였으며, Titianova 등18은 GAITRite를 사용하여 건강한 사람 62 명의 보행을 분석한 결과 오른쪽 보장은 $74.3 \mathrm{~cm}$, 왼쪽 보장은 $73.9 \mathrm{~cm}$ 라고 보고하였고, 활보장은 오른쪽 $148.6 \mathrm{~cm}$, 왼쪽 149.1 $\mathrm{cm}$ 라고 보고하였다.

Kilbreth 등의 연구에서는 큰볼기근에 테이핑을 적용하는 볼기 테 이핑(Gluteal taping)이 피부자극을 주어 근육 활성도를 향상시킬 수 도 있고, 고유수용성감각의 민첩성을 향상시킬 수 있으며, 또한 엉덩 관절 폄근의 활성을 증가시켜 골반이 넙다리뼈 위에 안정적으로 위 치할 수 있게 한다고 하였다. Kilbreath 등 ${ }^{19}$ 또한 뇌졸중 환자 50명을 대상으로 볼기 테이핑군과 위약 테이핑군으로 나눈 실험을 통해 관 절각도의 변화, 이동속도, 마비측, 비마비측의 보장의 변화에서 볼기 테이핑군은 위약테이핑에 비해 관절각도, 보행속도, 마비측, 비마비 측의 보장의 변화에 유의한 변화가 있었고 이를 통해 볼기테이핑 적 용이 뇌졸중 환자에게 효율적인 치료법임을 알 수 있었다.

본 연구에서 보행속도는 발목관절과 엉덩관절 동시적용 테이핑군 의 경우 적용 전 $48.83 \mathrm{~cm} / \mathrm{s}$ 에서 $57.63 \mathrm{~cm} / \mathrm{s}$ 으로 유의하게 증가하였고 분속수는 적용 전 $75.08 \mathrm{steps} / \mathrm{min}$ 에서 $82.84 \mathrm{steps} / \mathrm{min}$ 으로 유의하게 증가하였다 $(\mathrm{p}<0.05)$, 모든 군에서 보행 속도, 분속수의 변화에 대하여 유의한 향상을 보였다. 세 그룹 간 중재 전과 후의 차이는 발목관절과 엉덩관절 동시적용 테이핑군이 발목관절 테이핑군, 일반적인 물리치 료군보다 더 효과적이었다 $(\mathrm{p}<0.05)$. 보장은 발목관절과 엉덩관절 동시 적용 테이핑군의 경우 적용 전 마비측 $41.34 \mathrm{~cm}$, 비마비측 $34.73 \mathrm{~cm}$ 에서 마비측 $48.47 \mathrm{~cm}$, 비마비측 $41.42 \mathrm{~cm}$ 로 유의하게 증가하였고 $(\mathrm{p}<0.05)$, 
활보장은 발목관절과 엉덩관절 동시적용 테이핑군의 경우 적용 전 마 비측 $80.25 \mathrm{~cm}$, 비마비측 $79.86 \mathrm{~cm}$ 에서 마비측 $86.92 \mathrm{~cm}$, 비마비측 86.57 $\mathrm{cm}$ 로 유의하게 증가하였고 $(\mathrm{p}<0.05)$, 모든 군에서 보장, 활보장의 변화 에 대하여 유의한 향상을 보였다. 세 그룹 간 중재 전과 후의 차이는 발 목관절과 엉덩관절 동시적용 테이핑군이 발목관절 테이핑군, 일반적 인 물리치료군보다 더 효과적이었다 $(\mathrm{p}<0.05)$. 본 연구에서는 선행연구 결과와 일치하였는데 이는 발목관절과 엉덩관절 동시적용 테이핑이 다양한 과제와 환경의 변화에 적절한 반응을 이끌어 효율적인 균형 및 자세조절에 따른 보행 능력이 향상된 것으로 사료된다. 만성 뇌졸중 환자에게 입각기 보행 시 큰볼기근에 비탄력 테이핑을 적용 후 엉덩관 절의 신전이 향상되었으며, 발목관절의 테이핑은 감거나 붙이는 적용 방법에 따라 기계적 지지 및 자극을 촉진할 수 있으며, 접촉된 테이핑 으로 피부수용성 신호를 더욱 강하게 전달하며, 고유수용성 감각 향 상 및 관절의 바른 정렬을 촉진하여 관절의 안정성을 향상시켜 균형과 보행 능력의 향상을 이끌 수 있다고 하였다. ${ }^{8}$ 이는 자세동요에 따른 선 자세에서의 균형을 유지하기 위해 발목관절 전략이나 엉덩관절 전략 또는 두 전략을 함께 사용하는 부분에서 적용된 테이핑이 관절을 지 지하고 보호하여 기능적인 움직임을 수행할 수 있도록 하며, 인대의 보 강과 움직임의 제한을 통해 관절의 안정성을 향상시켜 본 연구 결과에 서도 발목관절과 엉덩관절 동시적용 테이핑군이 뇌졸중 환자의 균형 과 보행 특성을 개선시키는 데 효과가 있었다.

본 연구의 제한점은 운동의 강도나 운동 프로그램을 환자의 개개인 의 신체능력에 맞게 적절히 수정하여야 하지만 본 연구는 운동 강도를 개개인의 신체능력에 맞게 적절히 수정하지 않고, 4 주간 동일한 운동 프로그램을 실시했다는 점이다. 또한 연구 대상자 수가 작고, 연구 기 간이 4 주라는 짧은 기간이었다. 그러므로 다른 만성 뇌졸중 환자에게 도 같은 결과가 나타날 것으로 보기는 어렵다는 제한점이 있다.

만성 뇌졸중 환자에게 발목관절과 엉덩관절 동시적용 테이핑을 시행 한 후 균형 능력 및 보행 능력을 비교 분석한 후 다음과 같은 결론을 얻 었다. 본 연구의 결과에 따라 발목관절과 엉덩관절 동시적용 테이핑이 만성 뇌졸중 환자의 균형 능력 및 보행 능력에 효과가 있음을 확인할 수 있었다. 이러한 결과를 바탕으로 테이핑 적용은 만성 뇌졸중 환자의 치 료 프로그램 계획 시 기능 회복이 어려운 환자에게 균형 및 보행 능력을 증가시킬 수 있는 프로그램으로 적용될 수 있을 것으로 사료된다.

추후 연구는 대상자 수와 연구 기간을 늘리고, 운동강도와 시간이 만성 뇌졸중 환자의 균형과 보행에 효과적인지 규명할 필요가 있어 보인다.

\section{ACKNOWLEDGEMENTS}

이 논문은 2018년 삼육대학교 교내공모과제 연구비에 의해 씨여짐.

\section{REFERENCES}

1. Balasubramanian CK, Bowden MG, Neptune RR et al. Relationship between step length asymmetry and walking performance in subjects with chronic hemiparesis. Arch Phys Med Rehabil. 2007;88(1):43-9.

2. Geiger RA, Allen JB, O'Keefe J et al. Balance and mobility following stroke: effects of physical therapy interventions with and without biofeedback/forceplate training. Phys Ther. 2001;81(4):995-1005.

3. Wevers L, vande Port I, Vermue M et al. Effects of task-oriented circuit class training on walking competency after stroke. Stroke. 2009;40(7): 2450-9.

4. Jørgensen HS, Nakayama H, Raaschou HO et al. Outcome and time course of recovery in stroke. Part II: time course of recovery. The copenhagen stroke study. Arch Phys Med Rehabil. 1995;76(5):406-12.

5. Lord SE, McPherson K, McNaughton HK et al. Community ambulation after stroke: how important and obtainable is it and what measures appear predictive. Arch Phys Med Rehabil. 2004;85(2):234-9.

6. Hendricks HT, van Limbeek J, Geurts AC et al. Motor recovery after stroke: a systematic review of the literature. Arch Phys Med Rehabil. 2002;83(11):1629-37.

7. Kilbreath SL, Perkins S, McConnell J et al. Gluteal taping improves hip extension during stance phase of walking following stroke. Aust J Physiother. 2006;52(1):53-6.

8. Refshauge KM, Kilbreath SL, Raymond J. The effect of recurrent ankle inversion sprain and taping on proprioception at the ankle. Med Sci Sports Exerc. 2000;32(1):10-5.

9. Podsiadlo D, Richardson S. The timed up \& go: a test of basic functional mobility for frail elderly persons. J Am Geriatr Soc. 1991;39(2):142-8.

10. Finch E, Brooks D, Starford PW. Physical rehabilitation outcome measures. 2nd, Ottawa, Canadian Physiotherapy Association. 2002.

11. Tyson SF, Hanley M, Chillala J et al. Balance disability after stroke. Phys Ther. 2006;86(1):30-8.

12. Lee M, Kim M, Ahn C. Impact of concurrent inspiratory muscle training and tape on inspiratory muscle strength, endurance and pulmonary function. KSIM. 2014;2(3):65-73.

13. Shumway-Cook A, Woollacott MH. Motor control: translating research into clinical practice. Philadelphia, Lippincott Williams and Wilkins, 2007.

14. Dean E, Al-Obaidi S, De Andrade AD et al. The first physical therapy summit on global health: implications and recommendations for the 21st century. Physiother Theory Pract. 2011;27(8):531-47.

15. Holden MK, Gill KM, Magliozzi MR. Gait assessment for neurologically impaired patients. Standards for outcome assessment. Phys Ther. 1986; 66(10):1530-9.

16. Lunsford BR, Perry J. The standing heel-rise test for ankle plantar flexion: criterion for normal. Phys Ther. 1995;75(8):694-8.

17. Edward JW, Spiegelman D, Garland M et al. Physical activity, body mass index, and ovulatory disorder infertility. Epidemiology. 2002;13(2):18490.

18. Titianova EB, Mateev PS, Tarkka IM. Footprint analysis of gait using a pressure sensor system. J Electromyogr Kinesiol. 2004;14:275-81.

19. Kilbreath SL, Perkins S, Crosbie J et al. Gluteal taping improves hip extension during stance phase of walking following stroke. Aust J Physiother. 2006;52(1):53-6. 